visit a smallpox hospital. He had never been vaccinated, and so took this precaution before making the visit. Not only. was the local lesion typical, but most intense general symptoms developer, with high temperature and eruption. Shortly after recovery the visit to the hospital was made and an autopsy was performed on a body dead of variola. Within two weeks he developed a most virulent form of confluent variola, recovery followed, though life and death hung in the balance for a day or two.

Was this student successfully vaccinated? Most emphatically no, for the object of vaccination was not attained. Did the vaceination do any good? We can only surmise; without it I fear that death would have been on the lower side of the balance.

Our lack of facts regarding immunity leaves us at liberty to draw various conclusions from this case. However, I believe that we are justified in assuming that he was an extremely susceptible subject. I believe that revaccination should have been practiced immediately on recovery from the vaceinia, and revaccination slould have been continued until no reaction, either general or local, resuited.

This brings me to my ultimate conclusion and object. Vaccination should be repeated until no reaction, either general or local, resuits, with the use of an absolutely reliable virus and herein lies the only true test of "successful vaccination."

$$
\text { H. C. Crumrine, M.D. }
$$

\section{Opposes Making Dentists Semi-Physicians.}

\section{Cinicago, Ill., June 21, 1902}

To the Editor:--Dr. Peck's plan to teach physical diagnosis to dentists seems to me a highly superfluous one. To gradually wake the 40,900 dentists in this cointry semi-doctors is to add to the already much overcrowded medical profession an additional burden. The doctor seems to forget that a man who is not licensed to practice medicine has no business to do so, and if making a physical diagnosis and then advising the patient alongr such lines is not practice of medicine, what is it? He forgets, too, that while the dentist in such instances gets remunerated for his part of the work the doctor is thrown out of his legitimate fee. Nearly every patient who goes to a dentist is the patient of some physician, and it would be the height of discourtesy, to say nothing of the lack of necessity in $99 / 100$ of the cases, to request a physical examination before proceeding with the dental work. A dentist who has ordinary in telligence and judgment will not kecp a nervous woman in a chair for a long sitting, and if he can not discover her condition from casual observation he certainly can not from an unwelcome physical examination. Deniists have got along very well under the present conditions. We do not hear of any dire calan. ities befalling any of their patients. If dental professors will instruct their pupiis to be careful, to not want to get the work done too quickly for the money there is in it, they will eliminate all necessity for unusual retinements. So far as embarrassment to the dentist is concerned there could be none, as no patient expects him to do what he has no pretensions to. When ether or ebloroform is required he fefers the patient to his physician, who looks after all such details, relieving him-and properlyof all responsibility. Many dentists now prescribe for patients, thinking they know more thun a physician. Dr. Peck might, with equal force, suggest that symptomatology and pathology be added to the curricula of pharmacy schools that pharmacists might judge of the adaptability of prescriptions to the patients for whom they are asked to fiu them. What with the hypermultiplicily of medical sehools, free dispensaries, prescribing druggists, midwives and iaith healers, the regular physician has a hard road to travel without adding further to his burdens. Dr. Peck, no doubt, has found his medical knowledge useful, and if lie insists that dentists shoum have it let him likewise insist that they should take the medical degree. Physicians might as well have dentistry added to their curricula as the reverse proposition. How would the dentists like that? The doctor may say that $I$ am looking at it from a selfishly pecuniary standpoint rather than a high scientific one. This may be true to an extent, and I find justification in the trite but true saying that "self-preservation is the first law of Nature." 'The enemies of the medical profession are not the wholesale pharmaceutical houses, as many would have us believe, but are in the ranks of the profession itself, who, in their own selfish desire for success, start all kinds of medical schools which graduate all kinds of students, irrespective of their moral, physical or mental qualifications. They get the poor devil's money; in return the poor devil, who has to make a living, finds he ean not do it legitimately, so turns quack. No, we do not need more doctors nor half doctors. We need a profession whose leaders are ethical, not only in tongue but in acts. If they are sincere let these leaders subvert self, make one medical school out of three, instead of getting jealous of each other and making three out of one. Let them tell a prospective student that he has less charice to succeed in medicine than he has to win money at a horse race instead of evasively remarking "there is always room at the top." These latter observations are a little apart from my criticism of Dr. Peck's paper, but still, I think, are apropos.

\section{N. Clark Street.}

H. E. DunLop, M.D.

\section{Osteopaths Must Take the Usual Examination-Alabama Supreme Court Decision.}

Moxtgonery, Ala., July 2, 1902.

To the Editor:--Knowing the interest of The Jocrnal o1 the American Medical Association in all questions involving the practice of medicine, I send you a copy of a decision just rendered by the Alabama Supreme Court, the highest tribunal of the state, in a case which was appealed to that body last November. The decision is of great importance to the profession in Alahama, and in my judgment is of interest to the profession at large. To me it seems to present a "clear-cut" argument as te what eonstitules the practice of medicine. I am told by members of the legal profession that the Alabama Supreme Court occupies a high judicial rank, and I feel sure its position will not suffer from this decision, which was prepared by Judge $J$. R. 'lyson, and unanimously concurred in by the other members of the court. If you think it or any part of it is worthy a place in your valuable journal you are at liberty to use same. I am very respectfully,

$$
\text { R. S. HiLL. }
$$

THE SUPREME COURT OF ALABAMA.

xOVEMBER TERM, 1901, 6 DN., 479, E. EUGENe bragG VS. THE STATE OF ALABAMA. APPEAL FROM JEFFERSON CRIMINAL COURT. JUDGE: J. R. TYSON.

It is admitted that defendant was engaged in the practice of osteopathy as a profession and means of livelihood without having boards of medical examiners.

The most important question presented is whether the practice of osteopathy is "the practice of medicine in any of its branches or departments" within the meaning of Section 3261 of Civil code and 5333 of Criminal Code. The contention of defendant is, that it is not. He predicates his insistence mainly. indeed we may say wholly, upon the fact that in the practice of osteopathy no drugs or other medicinal substances are administered or applied, internally or externally ; nor is the knife used or any form of surgery resorted to in the treatment of diseases. In fact, the practitioners of that school of the healing art repudiate as remedial agents, all drugs, medicinal substances and the knife and other surgical instruments and appliauces. in the treatment of or alleviation of diseases and therefore need have no knowledge of their use. drugs and other medicinal sulstances or of the compounding and administerirg of drugs in the cure of diseases. Their method of treatment is entirely external, consisting of "a system of a manipulation of the limbs and body of the patient with the hands. by kneading, rubbing or pressing upon the parts of the body." However, in order to practice the profession of osteopathy skilfully and seientifically. it is admitted that the practitioner must know anatomy, physiology, hygiene, histology and pathology. Confessedly, the requirement of a knowledge on the part of the practitioners of all of these branches of the science of healing the sick or distas d is to enable him to skilfully determine the disease with which his patient is aftlicted and to aid him in making a proper application of bis system of manipulation. For it is entirely clear from the evidence that the practitioner does not make the same application of his remedy to all diseases, but that he applies such system of manipulation as is most remedial in alleviating or curing the particular disease he is called upon to treat. In other words. after a diagnosis of the disease of the patient. ho applies the remedy most suifable to its cure. confining it, however, to his system of manipulation as a remedial agent

So. too, a practitioner of medicine is required to know anatomy, physiology, hygiene, histologs. and pathology in order to enable his patient is suffering, and after so determining, he must also know 